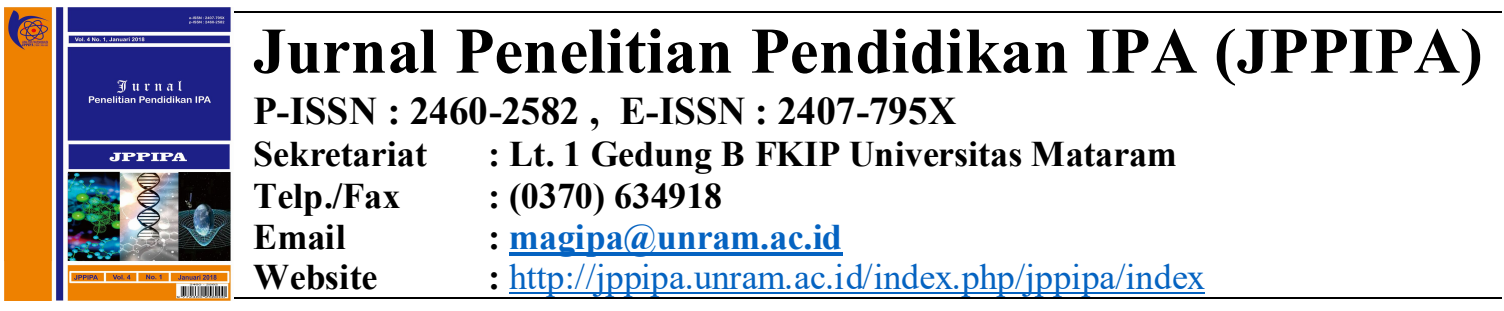

\title{
PENGARUH MODEL PEMBELAJARAN PROCESS ORIENTED GUIDED INQUIRY LEARNING (POGIL) TERHADAP PEMAHAMAN KONSEP IPA, KETERAMPILAN PROSES SAINS DAN KEMAMPUAN BERPIKIR KRITIS SISWA SMP NEGERI 3 PRINGGABAYA LOMBOK TIMUR.
}

\author{
Rustam $^{1)}$ Aguss Ramdani ${ }^{2)}$ Prapti Setijani ${ }^{3)}$ \\ Program Studi Magister Pendidikan IPA, Program Pascasarjana Universitas Mataram ${ }^{123}$ \\ Email: ?????
}

\begin{tabular}{|c|c|}
\hline Key Words & Abstract \\
\hline $\begin{array}{l}\text { POGIL, } \\
\text { understanding } \\
\text { Natural } \\
\text { Sciences } \\
\text { concept, Skill of } \\
\text { Sciences } \\
\text { Process and the } \\
\text { capability of } \\
\text { critical thinking }\end{array}$ & $\begin{array}{l}\text { This research is aimed at determining the effect of POGIL model } \\
\text { teaching on the understanding of Natural Science Concept, Skill of } \\
\text { Sciences Process, and Critical Thinking Capability of student in } \\
\text { photosynthesis. This research is a experiment with nonequivalent } \\
\text { control group design. The sample were selected randomly and the } \\
\text { hypothesis was analized with Manova and t-test. The rsearch } \\
\text { concludes that (1) there an effect of POGIL model teaching in } \\
\text { understanding Natural Sciences concept (2) there an effect of POGIL } \\
\text { model teaching on Skill of Sciences Process (3) there an effect of } \\
\text { POGIL model teaching on the capability of critical thinking (4) there } \\
\text { is simultaneous effect of the application of POGIL model teaching on } \\
\text { the Natural Sciences concept, Skill of Sciences Process and in the } \\
\text { capability of critical thinking. }\end{array}$ \\
\hline Kata Kunci & Abstrak \\
\hline POGIL, & oertujuall umtuk mengetaniur \\
\hline $\begin{array}{l}\text { Pemahaman } \\
\text { Konsep IPA, } \\
\text { Keterampilan } \\
\text { Proses Sains, } \\
\text { dan }\end{array}$ & $\begin{array}{l}\text { Pembelajaran di SMP Negeri } 3 \text { Pringgabaya belum dilaksanakan secara } \\
\text { inkuiri ilmiah (scientific inquiry) dalam upaya menumbuhkan } \\
\text { kemampuan berpikir, bekerja, dan bersikap ilmiah. Penelitian ini } \\
\text { merupakan kuasi eksperimen dengan desain nonequivalent control } \\
\text { group. Teknik pengambilan sampel dengan simple random sample. }\end{array}$ \\
\hline $\begin{array}{l}\text { Kemampuan } \\
\text { Berpikir Kritis }\end{array}$ & $\begin{array}{l}\text { Pengujian hipotesis menggunakan analisis Manova dan uji t. Hasil } \\
\text { penelitian menunjukkan bahwa (1) Terdapat pengaruh model } \\
\text { pembelajarn POGIL terhadap pemahaman konsep IPA, (2) Terdapat } \\
\text { pengaruh model pembelajaran POGIL terhadap keterampilan proses } \\
\text { sains, (3) Terdapat pengaruh model pembelajaran POGIL terhadap } \\
\text { kemampuan berpikir kritis, dan (4) Terdapat pengaruh secara simultan } \\
\text { penerapan model pembelajaran POGIL terhadap pemahaman konsep } \\
\text { IPA, keterampilan proses sains, dan kemampuan berpikir kritis. }\end{array}$ \\
\hline
\end{tabular}

PENDAHULUAN

Pembelajaran IPA sebaiknya dilaksanakan secara inkuiri ilmiah (scientific inquiry) dalam upaya menumbuhkan kemampuan berpikir, bekerja, dan bersikap ilmiah serta dapat 
mengkomunikasikannya sebagai aspek penting kecakapan hidup. Jufri (2013) menyatakan, pembelajaran disekolah lebih dari sekedar proses membantu siswa untuk belajar. Dalam hal ini, guru harus yakin bahwa siswa benar-benar terbantu untuk mempelajari materi pelajaran dan keterampilan yang dituntut dalam kurikulum. Secara teoritis, materi pelajaran dirancang agar siswa belajar dengan membangun pengetahuan dan keterampilan berdasarkan apa yang telah dipelajari sebelumnya dan mempersiapkan cara untuk menghadapi tantangan yang akan datang.

Hasil Ulangan Semester Bersama (USB) pada semester ganjil tahun pelajaran 2015/2016 menunjukkan bahwa pada mata pelajaran IPA nilai rata-rata untuk kelas VII adalah 60 , kelas VIII adalah 56, kelas IX adalah 54 dengan KKM 68, hal ini berarti bahwa nilai rata-rata hasil USB pada semester ganjil tahun pelajaran 2015/2016 masih rendah dari nilai KKM untuk mata pelajaran IPA.

Dengan demikian dapat dikatakan bahwa siswa kurang memahami konsep terhadap materi yang dipelajarinya, maka diperlukan suatu proses pembelajaran yang mengarahkan siswa untuk mencari tahu sendiri jawaban atas pertanyaan atau suatu masalah, sehingga membantunya untuk memperoleh pemahaman yang lebih mendalam Demikian pula dengan keterampilan proses sains dan berpikir kritis yang dimiliki oleh siswa masih sangat rendah, karena proses pembelajaran IPA yang dilaksanakan belum memfasilitasi siswa untuk melakukan penyelidikan ilmiah guna mendapatkan fakta-fakta yang mendukung atas jawaban terhadap pertanyaan yang mereka hadapi, model pembelajaran, yang dapat mengembangkan pemahaman konsep, keterampilan proses sains, dan kemampuan berpikir kritis.

Pemahaman konsep, keterampilan proses sains, dan kemampuan berpikir kritis pada siswa dapat dibangun dengan suatu model pembelajaran yang menerapkan komunikasi multi arah baik antar siswa maupun siswa dengan guru, model pembelajaran yang demikian bersifat student centered. Model pembelajaran yang menerapkan student centered salah satunya adalah Process Oriented Guided Inquiry Learning (POGIL). Hanson (2006) menerangkan bahwa dalam model pembelajaran POGIL siswa belajar secara berkelompok dalam aktivitas yang dirancang untuk meningkatkan penguasaan isi dari mata pelajaran dan mengembangkan kemampuan dalam proses belajar, berpikir, menyelesaikan masalah, berkomunikasi, kerja kelompok, managemen dan evaluasi. POGIL adalah pedagogi sains dan filosofi student centered yang berbasis riset dimana siswa beraktifitas didalam kelompok kecil dan terlibat dalam inkuiri terbimbing menggunakan materi yang sudah dirancang secara langsung membimbing siswa untuk membangun ulang pengetahuan mereka (Barthlow, 2011).

POGIL yang memiliki penekanan pada konten dan proses, dengan demikian memiliki kaitan dengan pemahaman dan keterampilan proses khususnya keterampilan proses sains seta berpikir kritis. Model Pembelajaran POGIL menurut Moog \& Spencer, (2008) memiliki dua tujuan yang luas yaitu untuk mengembangkan penguasaan konten melalui konstruksi pemahaman siswa sendiri, dan untuk mengembangkan serta meningkatkan keterampilan utama belajar seperti pemerosesan informasi, komunikasi oral dan tertulis, berpikir kritis, pemecahan masalah, metakognisi dan assesemen.

Berdasarkan pendapat diatas dapat dikatakan bahwa Model POGIL merupakan bagian dari model pembelajaran inkuiri terutama inkuiri terbimbing (guided inquiry) yang berorientasi proses untuk mempermudah pelaksanaan proses pembelajaran secara inkuiri. Dengan demikian POGIL memiliki penekanan pada proses dan konten yang berkaitan dengan aplikasi dari pemahaman konsep, keterampilan proses sains, dan berpikir kritis. Model pembelajaran POGIL penting untuk diterapkan karena dalam kegiatan pembelajarannya POGIL bekerja dalam 
bentuk tim sehingga kegiatan inkuiri terbimbing dapat digunakan untuk mengembangkan pemahaman dan pertanyaan, pemecahan masalah serta tanggung jawab individu. Hal ini sejalan dengan pendapat yang mengatakan bahwa model POGIL mengharuskan siswa untuk bekerja dalam kelompok-kelompok kecil, melihat model atau diagram, dan menjawab pertanyaan yang dirancang dengan hati-hati sehingga membimbing mereka untuk memahami materi pelajaran, dengan bimbingan yang minimal dari instruktur (Johnson, 2011)

Model POGIL merupakan elaborasi dari 3 komponen, yaitu tim belajar, aktivitas inkuiri terbimbing, dan metakognisi. Ketiga komponen tersebut dikemas melalui siklus belajar yang terdiri dari 3 fase yaitu eksplorasi, penemuan konsep, dan aplikasi (Hanson, 2006).

\section{METODOLOGI}

Jenis penelitian adalah quasy experiment dengan menggunakan desain nonequivalent control group design. Dengan rancangan pada Tabel 1 berikut. Tabel 1: Rancangan Penelitian

\begin{tabular}{cccc}
\hline Kelompok & Pretes & Perlakuan & Posttes \\
\hline $\mathrm{E}$ & $\mathrm{O} 1$ & $\mathrm{X}_{1}$ & $\mathrm{O} 2$ \\
$\mathrm{~K}$ & $\mathrm{O} 3$ & - & $\mathrm{O} 4$ \\
\hline
\end{tabular}

Keterangan:

(Sumber: Sugiyono, 2014:79)

E : Kelas Eksperimen

K : Kelas Kontrol

O1 : Pretes Kelas Eksperimen

$\mathrm{O} 2$ : Posttes Kelas Eksperimen

O3 : Pretes Keela Kontrol

O4 : Posttes Kelas Kontrol

Kegiatan penelitian diawali dengan pretes baik kepada kelas eksperimen maupun pada kelas kontrol. Pada kelas eksperimen diterapkan model pembelajaran $P O G I)$ dan kelas kontrol dengan model pembelajaran konvensional. Setelah mendapatkan perlakuan yang berbeda, kedua kelas diberikan posttes mengenai pemahaman konsep IPA, keterampilan proses sains dan kemampuan berpikir kritis.
Populasi dalam penelitian ini adalah semua siswa kelas VIII SMP Negeri 3 Pringgabaya Kabupaten Lombok Timur Tahun Pelajaran 2016/2017 yang terdiri atas 7 kelas. Teknik pengambilan sampel pada penelitian ini menggunakan teknik simple random sampling. Dari tujuh kelas populasi dipilih secara acak 4 kelas sampel. Keempat kelas tersebut dipilih lagi secara acak dua kelas meenjadi kelas eksperimen dan dua kelas menjadi kontrol.

Pengumpulan data dilakukan dengan menggunakan teknik tes. Tes Pemahaman konsep IPA untuk memngukur indikator pemahaman konsep yaitu (1) penerjemahan (translasi) (2) penafsiran (interpretasi) dan (3) ekstrapolasi awalnya (Bloom, 1956). Tes keterampilan proses sains yang digunakan untuk mengukur indikator keterampilan proses yaitu mengamati (observasi), Meramalkan (prediksi), berhipotesis, merencanakan percobaan, menggunakan alat/bahan, menerapkan konsep dan berkomunikas (Rustaman, 2005). Tes kemampuan berpikir kritis mengukur indikator kemampuan berpikir kritis yang mengacu pada indikator kemampuan berpikir kritis (Ennis, 1985) meliputi (1) memberikan penjelasan sederhana, (2) membangun keterampilan dasar, (3) menyimpulkan, (4) memberikan penjelasan (5) mengatur strategi dan taktik.

Teknik analisis data dalam penelitian ini adalah Independent Sample t Test dan uji manova dengan terlebih dahulu uji normalitas dan uji homogenitas. Uji normalitas menmggunakan Lilliefors (uji kecocokan Kolmogorov-Smirnov) yang diolah dengan software SPSS 22 for windows. Dengan kriteria Asymp. Sig. (2tailed) $>0,05$ data berdistibusi normal. Uji homogenitas dalam penelitian ini menggunakan uji Lavene Test dan uji Box's $M$. Uji Lavene Test bertujuan untuk mengetahui data pada masing-masing variabel terikat memiliki varians-kovarians yang homogen atau tidak. Uji Box's $M$ bertujuan untuk mengetahui data pada semua variabel secara bersama-sama memikili varians-kovarians yang homogen 
atau tidak. Kriteria keputusan jika Sig. > 0,05 maka data homogen atau sebaliknya. Pengolahan data menggunakan software SPSS

Pengujian hipotesis terhadap masingmasing variabel terikat menggunakan uji Independent Sample $t$ Test, dengan kriteria jika $t_{\text {hitung }}>\mathrm{t}_{\text {tabel }} \mathrm{H}_{0}$ ditolak pada taraf signifikasi 0,05 atau sebaliknya, sedangkan untuk menguji pengaruh variabel bebas terhadap variabel terikat secara simultan digunakan uji manova dengan kriteria jika angka Pillai's Trace, Wilks' Lambda, Hotelling's Trace, dan Roy's Largest Root menunjukkan signifikasi (Sig) $>0,05$, maka $\mathrm{H}_{0}$ diterima dan jika angka signifikasi (Sig) $<0,05$, maka $\mathrm{H}_{0}$ ditolak. Perhitungan menggunakan software SPSS 22 for windows.

\section{HAIL DAN PEMBAHASAN}

Dekripsi Hasil Penelitian terdapat pada Gambar 1 berikut.

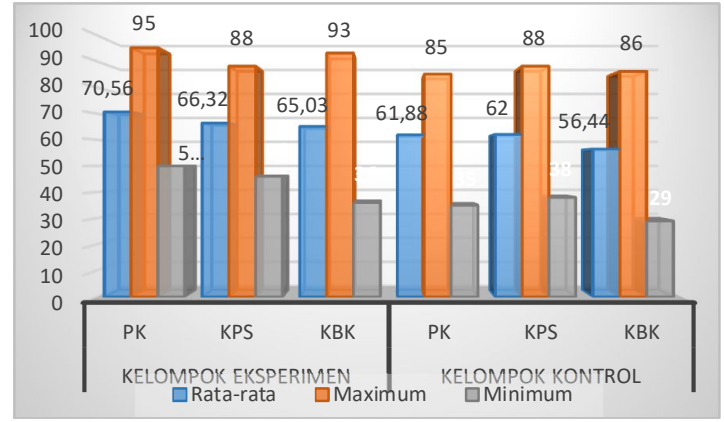

Gambar 1: Tabel Deskripsi data kelompok Eksperimen dan Kontrol
Keterangan:

PK : Pemahaman konsep IPA

KPS : Keterampilam Proses Sains

KBK : Kemampuan Berpikir Kritis

Dari Gambar diatas menunjukkan nilai tertiggi pemahaman konsep IPA pada kelompok eksperimen adalah 95 dan terendah 50 dengan rata-rata 70,56, pada kelompok kontrol nilai tertinggi 85, dan terendah 35 dengan rata-rata 61,88. Dengan demikian maka dapat dikatakan bahwa nilai variabel keterampilan proses sains pada kelompok eksperimen memperoleh nilai tertinggi 88 dan terendah 46 dengan rata-rata 66,32 . Pada kelompok kontrol nilai tertinggi 88 , terendah 38 dengan rata-rata 61,88 . Nilai kemampuan berpikir kritis untuk kelompok eksperimen tertinggi 93, teremdah 36, dan rata-rata 65,03 , sementara pada kelompok kontrol nilai tertinggi 86 dan terendah 29 dengan rata-rata 56,44. Dari kenyataan diatas dapat dikatakan bahwa kelompok eksperimen yang menerapkan model pembelajaran POGIL memiliki nilai ratarata yang lebih tinggi dari kelompok kontrol yang menerapkan model konvensional.

Independent Sample $t$ Test dalam penelitian ini untuk menguji pengaruh variabel bebas pada masing-masing variabel terikat. Data hasil uji tersebut dapat dilihat pada Tabel berikut:

Tabel 2: Independent Samples t Test

\begin{tabular}{|c|c|c|c|c|c|c|c|c|}
\hline \multirow{3}{*}{\multicolumn{2}{|c|}{ Variable }} & \multicolumn{7}{|c|}{ t-test for Equality of Means } \\
\hline & & \multirow{2}{*}{$\mathrm{t}$} & \multirow{2}{*}{ df } & \multirow{2}{*}{$\begin{array}{l}\text { Sig. (2- } \\
\text { tailed) }\end{array}$} & \multirow{2}{*}{$\begin{array}{c}\text { Mean } \\
\text { Difference }\end{array}$} & \multirow{2}{*}{$\begin{array}{l}\text { Std. Error } \\
\text { Difference }\end{array}$} & \multicolumn{2}{|c|}{$\begin{array}{c}95 \% \text { Confidence Interval } \\
\text { of the Difference }\end{array}$} \\
\hline & & & & & & & Lower & Upper \\
\hline $\begin{array}{l}\text { Pemahaman } \\
\text { Konsep IPA }\end{array}$ & $\begin{array}{l}\text { Equal variances } \\
\text { assumed }\end{array}$ & 4.161 & 142 & .000 & 8.681 & 2.086 & 4.556 & 12.805 \\
\hline $\begin{array}{l}\text { Keterampilan } \\
\text { Proses Sains }\end{array}$ & $\begin{array}{l}\text { Equal variances } \\
\text { assumed }\end{array}$ & 2.126 & 142 & .035 & 4.319 & 2.032 & .304 & 8.335 \\
\hline Berpikir Kritis & $\begin{array}{l}\text { Equal variances } \\
\text { assumed }\end{array}$ & 3.564 & 142 & .000 & 8.583 & 2.409 & 3.822 & 13.345 \\
\hline
\end{tabular}

Hasil uji Independent Sample $t$ Test pada variabel. Variabel pemahaman konsep
IPA memiliki nilai thitung sebesar 4,161 dan nilai $t_{\text {tabel }}$ pada taraf signifikan 0,05 sebesar 
1,977 berarti $t_{\text {hitung }}>t_{\text {tabel }}$. Dengan demikian maka dapat disimpulkan bahwa $\mathrm{H}_{0}$ ditolak dan $\mathrm{H}_{1}$ diterima, artinya terdapat pengaruh model pembelajaran POGIL terhadap pemahaman konsep IPA.

Variabel keterampilan proses sains mempunyai nilai thitung sebesar 2,126 dan $t_{\text {tabel }}$ pada taraf signifikan 0,05 sebesar 1,977, berarti nilai $t_{\text {hitung }}>t_{\text {tabel. }}$. Dengan demikian dapat disimpulkan bahwa $\mathrm{H}_{0}$ ditolak dan $\mathrm{H}_{1}$ diterima artinya terdapat pengaruh model Tabel 3: Hasil Uji Multivariat.

\begin{tabular}{llllrlrrr}
\hline & Effect & Value & F & \multicolumn{2}{c}{$\begin{array}{c}\text { Hypothesis } \\
\text { df }\end{array}$} & Error df & Sig. & $\begin{array}{c}\text { Partial Eta } \\
\text { Squared }\end{array}$ \\
\hline $\begin{array}{l}\text { Model } \\
\text { Pembelajaran }\end{array}$ & Pillai's Trace & 0.513 & 49.235 & 3.000 & 140.000 & 0.000 & 0.513 \\
\cline { 2 - 8 } & Wilks' Lambda & 0.487 & 49.235 & 3.000 & 140.000 & 0.000 & 0.513 \\
\cline { 2 - 8 } & Hotelling's Trace & 1.055 & 49.235 & 3.000 & 140.000 & 0.000 & 0.513 \\
\cline { 2 - 8 } & Roy's Largest Root & 1.055 & 49.235 & 3.000 & 140.000 & 0.000 & 0.513 \\
\hline
\end{tabular}

Berdasarka Tabel 3 diatas didapatkan nilai Sig. yang diuji dengan prosedur Pillai's Trace, Wilks' Lambda, Hotelling's Trace, dan Roy's Largest Root semuanya menunjukan angka 0,000 artinya nilai $\mathrm{Sig}<$ 0,05 sesuai dengan kriteria diatas dapat disimpulkan bahwa $\mathrm{H}_{0}$ ditolak dan $\mathrm{H}_{1}$ diterima artinya terdapat pengaruh secara simultan model pemebelajaran POGIL terhadap Pemahaman konsep IPA, Keterampilan proses sains, dan kemampuan berpikir kritis.

Hasil analisis data menunjukkan bahwa terdapat pengaruh model pembelajaran POGIL terhadap pemahaman konsep IPA. Pengaruh ini disebabkan oleh penerapan model POGIL yang mengarahkan siswa lebih mudah memahami materi pembelajaran karena diajarkan melalui kerjasama tim atau kelompok dalam menyelesaikan soal dan permasalahan yang diberikan oleh guru. Hal ini sesuai dengan pernyataan yang dikemukakan oleh Brown (2010) bahwa belajar dalam tim memungkinkan siswa lebih mengembangkan penalarannya pada tingkat yang lebih tinggi, karena diskusi yang dilakukan terjadi pembagian peran dalam kelompok, sehingga membuat pembelajaran lebih menarik dan membantu terjadinya kerja sama antar anggota yang pembelajaran POGIL terhadap keterampilan proses sains. Nilai $t_{\text {hitung }}$ untuk variabel kemampuan berpikir kritis adalah 3.564 dan $t_{\text {tabel }}$ pada taraf signifikan 0,05 sebesar 1,977, berarti $t_{\text {hitung }}>t_{\text {tabel }}$ maka dapat disimpulkan bahwa $\mathrm{H}_{0}$ ditolak dan $\mathrm{H}_{1}$ diterima, artinya terdapat pengaruh model pembelajaran POGIL terhadap kemampuan berpikir kritis.

Hasil uji manova dapat dilihat pada Tabel berikut. mengakibatkan tumbuhnya keaktifan siswa dalam pembelajaran. Selain itu pembelajaran dengan guided inquiry dapat mendorong siswa secara aktif untuk menggali pengetahuannya sendiri sehingga siswa dapat menjadi pribadi yang mandiri, aktif, serta terampil dalam memecahkan masalah berdasarkan informasi dan pengetahuan yang didapatkan (Natalina, 2013). Dengan demikian model pembelajaran dapat mendorong keaktifan siswa untuk menggali pengetahuannya secara madiri dalam memecahkan masalah pada konsep yang sedang dipelajarinya.

Kelebihan model pembelajaran POGIL terlihat dari kesiapan siswa dalam proses pembelajaran, karena siswa terlebih dahulu mempersiapkan diri mengenai materi yang akan dipelajari. Oleh karena itu siswa memiliki kesiapan berupa pengetahuan dan pemahaman konsep awal pada materi yang akan dipelajarinya (Rahayu \& Pamelasari 2015). Dalam menerapkan model pembelajaran POGIL pada setiap akhir pembelajaran guru mengharuskan siswa untuk membaca materi pembelajaran yang akan dipelajari pada pertemuan berikutnya. Dengan demikian siswa yang telah mempelajari materi terlebih dahulu akan lebih mudah dalam menemukan konsep, sehingga pemahaman 
terhadap konsep pada materi yang dipelajarinya semakin kuat. Selain itu konsep yang ditemukan mendapat konfirmasi dari tim atau kelompoknya bahkan dari guru.

Berdasarkan hasil analisis data menunjukkan bahwa terdapat pengaruh model pembelajaran POGIL terhadap keterampilan proses sains. Hal ini disebabkan karena kelompok eksperimen yang menerapkan model pembelajaran POGIL melakukan percobaan atau praktikum. Dengan melakukan percobaan siswa mengalami langsung proses yang dipelajarinya sehingga benar-benar terfokus terhadap apa yang sedang dilakukan atau dipelajarinya. Keterampilan proses sains dapat dikembangkan melalui pengalaman langsung karena siswa dapat lebih menghayati proses atau kegiatan yang sedang dilakukan (Rustaman, 2005).

Banyak manfaat yang didapatkan dengan melibatkan siswa dalam kegiatan laboratorium antara lain meningkatkan kebermaknaan belajar, pemahaman konseptual dan pemahaman tentang sifat sains (Hofstein, at al 2005). Oleh karena itu keterampilan proses sains dapat dilatih dari deskripsi data-data hasil penelitian, fenomena-fenomena alam yang sudah diketahui, dan peralatan sederhana yang ada disekitar siswa. Menurut Jufri (2013) proses pembelajaran bukan sekedar kegiatan menyampaikan dan menjelaskan konsep yang dipelajari, tetapi melibatkan siswa untuk membangun pengetahuan dan keterampilan, merumuskan masalah melalui kegiatan laboratorium.

Penerapan model pembelajaran POGIL berpengaruh teerhadap kemampuan berpikir kritis. Meningkatnya kemampuan berpikir kritis siswa ini disebabkan oleh penerapan model pembelajaran POGIL yang memberikan kesempatan pada siswa untuk berpikir dalam menyelesaikan masalah yang ditemukan dalam proses pembelajaran. Hanson (2006) menerangkan bahwa dalam model POGIL siswa belajar secara berkelompok dalam aktivitas yang dirancang untuk meningkatkan penguasaan isi dari mata pelajaran dan mengembangkan kemampuan dalam proses belajar, berpikir, menyelesaikan masalah, berkomunikasi, kerja kelompok, managemen dan evaluasi. Lebih lanjut Hanson (2006) menyatakan bahwa pembelajaran POGIL melibatkan siswa dalam mengembangkan informasi, pengetahuan, dan membantu siswa mengembangkan pemahaman dengan menerapkan siklus belajar dalam kegiatan inkuiri terbimbing.

Model pembelajaran POGIL mengajak siswa berpikir melalaui percobaan, dalam penelitian ini percobaan yang dilakukan adalah tentang fotosintesis dalam rangka menganalisis dan menyimpulkan hasil percobaan sehingga siswa memiliki kemampuan berpikir kritis. Penelitian Liliasari dan Tanwil (2013), Subarkah, dkk (2013) juga menunjukkan bahwa model pembelajaran POGIL dapat mengembangkan keterampilan berpikir kritis. Zawadzki (2010) menyatakan bahwa peningkatan keterampilan berpikir kritis siswa terjadi melalui POGIL, karena siswa mengalami pembelajaran yang bermakna. Dalam POGIL, siswa menganalisis hasil eksperimen dibimbing dengan berbagai pertanyaan kritis yang berurutan dan berkesinambungan, pada akhirnya siswa dapat membuat kesimpulan dengan benar sehingga terbangun kemampuan berpikir kritis.

Hasil analisis data juga menunjukkan bahwa terdapat pengaruh secara simultan model pembelajaran POGIL terhadap Pemahaman konsep IPA, keterampilan proses sains, dan kemampuan berpikir kritis. Model Pembelajaran POGIL terbukti juga secara teoritis mempengaruhi Pemahaman konsep, keterampilan proses sains, dan kemampuan berpikir kritis pada siswa dalam pembelajaran IPA. Ini sesuai dengan penelitian yang dilakukan oleh Johnson (2011), model pembelajaran POGIL lebih memberikan pengaruh dalam berpikir kritis menyelesaikan masalah. Sejalan dengan pendapat ini Villagonzalo (2014) meneliti tentang perbandingan kinerja siswa selama pembelajaran yang diterapkan model 
POGIL dan model tradisional. Ia menyimpulkan bahwa model POGIL merupakan suatu model pembelajaran yang efektif untuk meningkatkan performansi dan kinerja akademis siswa.

Penelitian lain yang berkaitan dengan penerapan model pembelajaran POGIL Widyaningsih (2012) menyatakan bahwa model POGIL memberikan pengaruh positif terhadap hasil belajar kognitif, afektif dan kreatifitas siswa. Zasmita dan Kaniawati (2015) menyimpulkan bahwa secara teoritis model pembelajaran process oriented guided inquiry learning (POGIL) berpengaruh positif terhadap keterampilan proses sains (KPS) dan kemampuan kognitif siswa. Ningsih, dkk (2012) juga menyatakan bahwa model POGIL dapat meningkatkan kemampuan berpikir kritis serta meningkatkan aspek berhipotesis, menganalisis dan menyimpulkan. Dari berbagai hasil penelitian yang telah dilakukan diatas dapat disimpulkan bahwa model pembelajaran POGIL memberikan hasil yang positif terhadap pemahaman konsep IPA, keterampilan proses sains, dan kemampuan berpikir kritis. Dengan demikian model pembelajaran POGIL dapat diterapkan pada mata pelajaran IPA karena dalam proses pembelajaran ini siswa dilatih untuk mengkonstruksi sendiri kemampuan kognitifnya, memberikan fasilitas pada siswa untuk melatih keterampilan proses sainsnya dan menumbuhkan kreativitas dalam berpikir. Dengan demikian konsep yang dipelajari akan mudah dipahami, kemudian dibuktikan melalui percobaan atau praktikum untuk membangun keterampilan proses sainsnya dan diberi kesempatan untuk menilai kinerjanya serta berpikir bagaimana memperbaiki kekuranganya.

\section{KESIMPULAN}

Berdasarkan hasil penelitian dan pembahasan yang telah dilakukan maka dapat disimpulakan sebagai berikut: (1) Terdapat pengaruh yang positif dari penerapan model pembelajaran POGIL terhadap Pemahaman konsep IPA. Dalam hal ini model pembelajaran POGIL menekankan pada pembentukan konsep secara mandiri oleh siswa dengan bimbingan guru, sehingga memberikan kesan yang mendalam terhadap konsep yang dipelajarinya. (2) Terdapat pengaruh yang positif dari penerapan model pembelajaran POGIL terhadap keterampilan proses sains. Dalam proses pembelajaran dengan model POGIL siswa melakukan kegiatan praktikum atau percobaan sebagai upaya membuktikan konsep atau teori yang sudah dipahaminya. (3) Terdapat pengaruh yang positif dari penerapan model pembelajaran POGIL terhadap kemampuan berpikir kritis. Dalam hal ini siswa mengekplorasi permasalahan sebagai respon berpikir kritis, yang berupa pertanyaan yang mengarahkan untuk mengidentifikasi konep dan pemahaman akan konsep yang dibangun serta aplikasi dari pengetahuan. (4) Terdapat pengaruh secara simultan dari penerapan model pembelajaran POGIL terhadap Pemahaman konep IPA, keterampilan proses sains, dan kemampuan berpikir kritis.

\section{DAFTAR PUSTAKA}

Barthlow, M. J. 2011. The Effectiveness of Process Oriented Guided Inquiry Learning to Reduce Alternate Conception in Secondary Chemistry. Dissertation Doctor Liberty University: Diakses pada digital. commons. Liberty.edu/.../viewcontent.cgi? Tanggal 15 September 2015

Bloom, B. S., 1956 Taxonomy of Educational Objectives, The Clasification of Educational goal. Canada: David McKay Company, Inc

Ennis, R. H. 1985. A Logical Basic for Measuring Critical Thinking Skill. New Jersey: Printice Hall

Brown,P. J. P. 2010. Process-oriented guided- inquiry learning in an introductory anatomy and 
physiology course with a diverse student population. Advan in Physiol Edu 34 (2):150-155. Diakses tanggal 11 Oktober 2016

Hanson, D.M. 2006. Instructor's Guide to Process-Oriented GuidedInquiry Learning. Lisle. Pacific Crest.

Hofstein, A., Navon, O., Kipnis, M., Naaman, R. M. 2005. Developing Students' Ability to Ask More and Better Questions. Journal of Research in Science Teaching. 2005. Wiley Periodicals, Inc. Vol. 42(7): 791-806 diakses pada onlinelibrary.wiley.com/

doi/10.1002/tea.20072/full 22 Juni 2016

Johnson, C. 2011. Activities Using ProcessOriented Guided Inquiry Learning (POGIL) In The Foreign Language Classroom. A Journal of the American Association of Teachers of German, 14 (1): 30-38. Diakses dari http://www. aatg.org/. Tanggal 17 Maret 2016

Jufri, W. 2013. Belajar dan Pembelajaran Sains. Bandung: Pustaka Reka Cipta.

Liliasari \& Tawil. (2013).Berpikir kompleks dan Implementasinya dalam Pembela-jaran IPA. Makasar: Badan Penerbit UNM

Moog, R. S. \& Spencer N.J. 2008. In Process Oriented Guided Inquiry Learning (POGIL). ACS Symposium Series. Washington DC: American Chemical Society

Natalina, M. 2013. Penerapan model pembelajaran inkuiri terbimbing (guided inquiry) untuk meningkatkan sikap ilmiah dan hasil belajar biologi siswa kelas XI IPA SMA N 5 Pekanbaru tahun ajaran 2011/2012. Prosiding Semirata FMIPA Universitas Lampung Lampung: 2013

Ningsih, S.M., Bambang S.,\& Sopyan, A. 2012. Implementasi Model Pembelajaran Process Oriented Guided Inquiry Learning (POGIL) Untuk Meningkatkan Kemampuan Berpikir Kritis Peserta didik. Unnes Physics Education Journal, 1(2):44-52. Diakses dari http://journal.unnes.ac.id/ sju/ index.php/upej, tanggal 10 Des. 2015

Rahayu, D.P, dan Pamelasari, S.D, 2015. Pengaruh Model Pembelajaran Process Oriented Guided Inquiry Learning Terhadap Kemampuan Berpikir kritis Peserta Didik pada Materi Perubahan Benda, USEJ 4(3)(2015). Diakses dari http://journal, unnes.ac.id/sju/index.php/usej. tanggal 16 Februari 2016

Rustaman N.Y., 2005. Strategi Belajar Mengajar Biologi. Malang: UM Press

Subarkah, C.Z., Windayani, N., \& Latief, B. (2013). Penerapan Metode POGIL (ProcessOriented Guided Inquiry Learning) padapembelajaran Titrasi Asam-Basa. Prosiding Seminar Nasional Penelitian, Pendidikan, dan Penerapan MIPA (hlm.239-244). Yogyakarta: FPMIPA UNY.

Sugiyono, 2014. Metode Penelitian Kunatitatif Kualitatif dan $R \& D$ Bandung: Alfabeta.

Villagonzalo, E.C. 2014. Process Oriented Guided Inquiry Learaning: An Effective Approach in Enhancing Studens's Academic Performance. $D L S U$ Research Congres 
Widyaningsih, S.Y., Haryono, Sulistyo, S. 2012. Model MFI dan POGI Ditinjau dari Aktifitas Belajar dan Kreativitas Siswa terhadap Prestasi Belajar. Jurnal Inkuiri, 1(3): 266275.

Zasmita, dan Karniawati, 2015. Pengaruh Model Pembelajaran Process Oriented Guided Inquiry Learning Terhadap Keterampilan Proses Sains Dan Kemampuan Kognitif Siswa Pada Mata Pelajaran Fisika EDUSAINS, 7(2), 2015, 191-201. Diakses dari http:// journal.uinjkt.ac.id/index.php/edus ains tanggal 30 Maret 2016

Zawadzki, R. 2010. Is Process-Oriented Guided-Inquiry Learning (POGIL) Suitable as a Teaching Method in Thailand's Higher Education? Asian Journal on Education and Learning, 1 (2):6674. Diakses dari www.ajel.info Tanggal 20 Desember 2015 